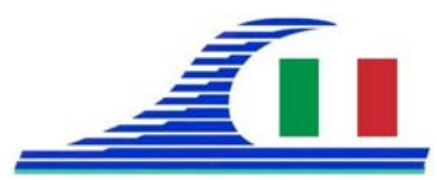

Conférence Méditerranéenne Côtière et Maritime EDITION 3, FERRARA, ITALIA (2015)

Coastal and Maritime Mediterranean Conference

Disponible en ligne - http://www.paralia.fr - Available online

\title{
Sustainable beach design for Raf Raf, Tunisia
}

\section{Nicholas GRUNNET ${ }^{1}$, Sten KRISTENSEN ${ }^{2}$, Kasper KAERGAARD ${ }^{2}$, Jort WILKENS ${ }^{3}$, Béchir NASRA ${ }^{4}$}

1. DHI France, Coastal \& Offshore Department, 4 rue Edouard Nignon, CS 47202, 44372 Nantes Cedex 3, France.

ngr@dhigroup.com

2. DHI Denmark, Coastal and Estuarine Dynamics, Agern Allé 5, 2980 Hørsholm. skr@dhigroup.com,kak@dhigroup.com

3. Inros Lackner, Linzer Str. 3, 28359 Bremen, Germany. jort.wilkens@inros-lackner.de

4. Coastal Protection and Planning Agency, Ministry of Environment and Sustainable Development, 2, Rue Mohamed Rachid Ridha, Le Bélvèdére, 1002 Tunis, Tunisia. mb.nasra@apal.nat.tn

\begin{abstract}
:
The beach at Raf Raf, Tunisia, has a high recreational use. Continuous erosion due to gradients in the littoral drift combined with urban developments placed close to the beach has reduced the beach width. In order to re-establish the wide beach, an extensive modelling study has been conducted by DHI by use of the new MIKE21 Shoreline Morphology FM model. The numerical study was used to investigate possible mitigation scenarios, which included beach nourishment and different types of stabilising structures. Finally an optimisation of the sand placement was undertaken in order to reduce costs of nourishment. The criteria for selecting the final mitigation scenario were largely based on longevity of the solution thus reducing the need for continuous maintenance.
\end{abstract}

The new shoreline model proved to be a valuable tool for comparing different mitigation scenarios in a systematic manner. Based on the model results it was possible to select a mitigation scenario which best satisfies the Client's needs.

The implementation of the new beach design is expected to be finished in 2016.

Keywords: MIKE21, Hybrid model, Shoreline model, Beach design, Morphology, Submerged breakwater, Groyne.

\section{Introduction}

Raf Raf beach is located approximately $40 \mathrm{~km} \mathrm{~N}$ from the capital Tunis of Tunisia and is characterised by the presence of a headland in the West and a beach which follows the shape of a logarithmic spiral. In the eastern end of the beach rocky outcrops appear as a result of continuous erosion. The beach has a high recreational value for tourists and locals. The beach is typically wide in the eastern end, while urban development 
Côtes méditerranéennes menacées :

Risques et défis dans le contexte du changement climatique

along the western end of the bay has resulted in construction of a rubble mound revetment with little or no beach in front of it.

The beach is under continuous erosion because the net littoral drift is towards east and little or no sediment is supplied to the bay from west. A coastal study and beach design has been carried out in order to mitigate the effects of the ongoing erosion and sustain the recreational value of the beach. The focus of the study is to secure a wide beach along the eastern half of the bay through a combination of hard and soft solutions.
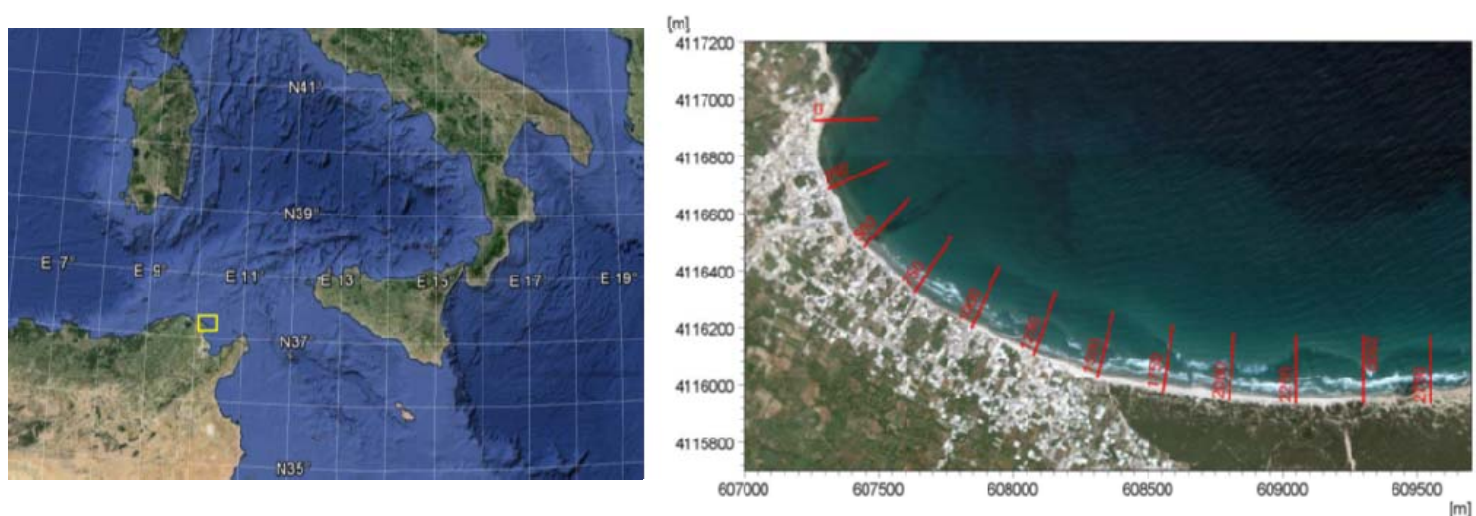

Figure 1. General setting of the study area in Tunisia (left) and zoom of Raf Raf site with indication of applied baseline (right). Background pictures from Google Earth.

\section{Methodology}

The beach design is supported by 11 year simulations with morphological evolution using DHIs new 2D shoreline evolution model, MIKE21 Shoreline Morphology FM. The model builds on the area model with a dynamic coupling of a hydrodynamics module, a spectral wave module and a sand transport is module (non-cohesive sediment). Morphological evolution is however constrained by forcing the bed update in the model in terms of seaward or landward movement of the shoreline in response to accretion or erosion as described in (KAERGAARD \& FREDSOE 2013; KRISTENSEN et al., 2010). Previous application of the model includes determination of shoreline response to breakwaters, (DRØNEN et al., 2011; KAERGAARD et al., 2014) and development due to mega nourishment, (KAERGAARD \& DRØNEN, 2015).

The morphological model is first setup to reproduce the overall sediment budget obtained by analysis of the bathymetric surveys carried out in 2000 and 2014. Successful setup included: High flow resistance over the reef in the western end of the bay and a sediment availability map to mimic the reduced supply of sand from west.

After having calibrated the model to the existing conditions, a number of scenarios have been investigated. The scenarios were composed of beach nourishment combined with stabilising structures such as submerged shore parallel breakwaters (SBW) and terminal groynes. Table 1 lists the characteristics of some of the scenarios. 
Mediterranean coasts at threat:

Hazards and challenges in the context of climate variability

Table 1. Characteristics of some of the tested scenarios.

\begin{tabular}{ll}
\hline Scenario & Characteristics \\
\hline 3 SBW & $250,000 \mathrm{~m}^{3}$ beach nourishment, giving $30 \mathrm{~m}$ accretion \\
& $3 \mathrm{SBW} 175 \mathrm{~m}$ long located $350 \mathrm{~m}$ apart and $250 \mathrm{~m}$ from \\
& the coast \\
& $450,000 \mathrm{~m}^{3}$ beach nourishment, giving up to $93 \mathrm{~m}$ \\
Terminal groyne & accretion \\
& 1 terminal groyne, $370 \mathrm{~m}$ long located at eastern end \\
\hline
\end{tabular}

\section{Synthesis of results from the study}

Two of the investigated scenarios included a combination of a 250,000 $\mathrm{m}^{3}$ nourishment and construction of submerged shore parallel breakwaters located inside the active profile. The nourishment gives a $30 \mathrm{~m}$ shoreline advance over approximately $2000 \mathrm{~m}$. The shoreline model is combined with a $2 \mathrm{D}$ bed update over the submerged structures to allow bypass of sediment over the structure.

The calculated shoreline response for one of the scenarios (with three submerged breakwaters) is shown in Figure 2, in terms of "additional beach width" which is defined as the width of the beach compared to the existing beach position. The nourishment is therefore directly derived from the 2001 result. The figure shows that the model predicts formation of salients within the first year. However, because the breakwaters are submerged and located inside the active profile, they do not reduce the longshore transport completely thereby resulting in a continuous retreat of the shoreline. Similar results were also obtained for a scenario with 5 submerged breakwaters.
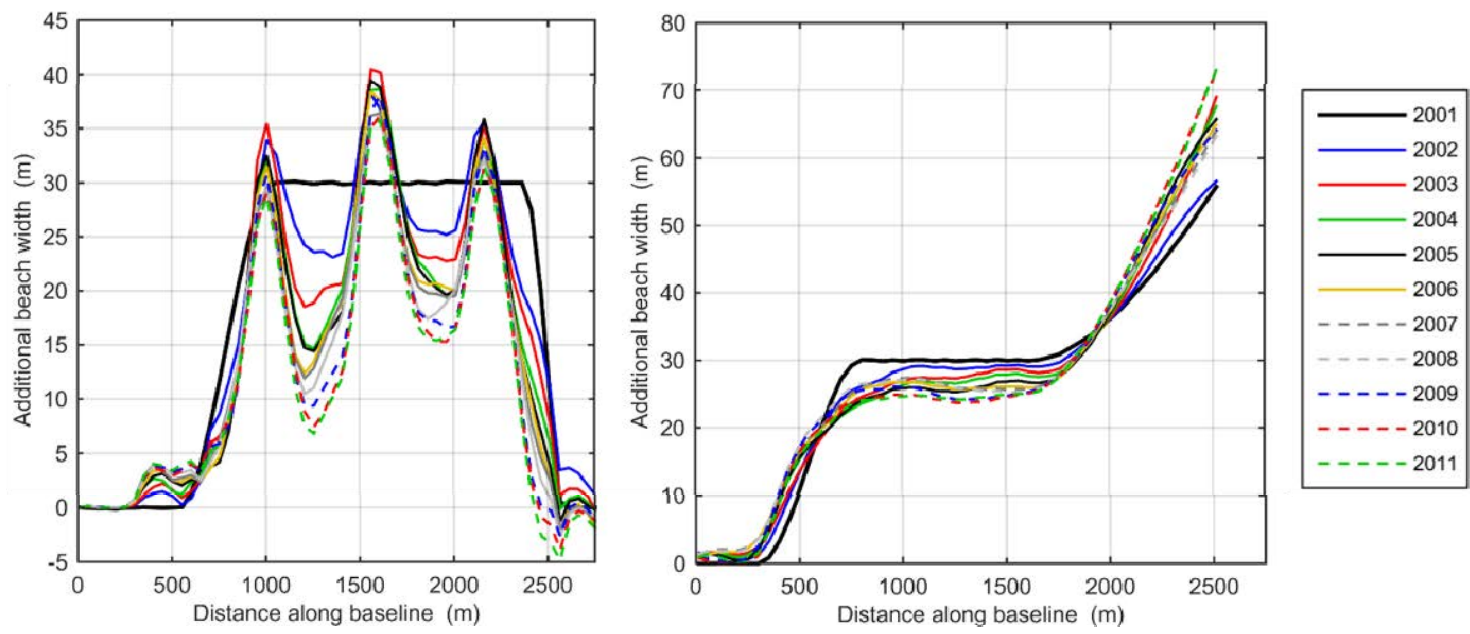

Figure 2. Results from 10 years of $2 \mathrm{D}$ shoreline modelling for the scenario with three submerged breakwaters (left) and a terminal groyne at the eastern end (right).

The figure shows additional beach width. 
Côtes méditerranéennes menacées :

Risques et défis dans le contexte du changement climatique

A final scenario was investigated which included a larger nourishment of $450,000 \mathrm{~m}^{3}$ and a terminal groyne. In the final scenario the beach is designed such that it will slowly turn towards the equilibrium orientation, thus resulting in erosion along the central part and accretion along the western and eastern end. The slowly turning beach will over the years reduce the littoral transport further towards zero thereby ensuring the longevity of the nourishment. The simulated shoreline response for the final scenario is shown in the previous Figure 2.

\section{Acknowledgements}

This work was made possible by funding from the KfW Development Bank in Germany.

\section{References}

KAERGAARD K., FREDSOE J. (2013). A numerical shoreline model for shorelines with large curvature, Coastal Engineering, Vol. 74, pp 19-32. http://dx.doi.org/10.1016/j.coastaleng.2012.11.011

KAERGAARD K., DROENEN N. (2015). A Hybrid Shoreline Model for the Sand Engine: Comparison with Observations and Long Term Predictions. in The Proceedings of the Coastal Sediments 2015, San Diego, California.

KAERGAARD K., MORTENSEN S., KRISTENSEN S., DEIGAARD R., TEASDAL, R., HUNT S. (2014). Hybrid shoreline modelling of shoreline protection schemes, Palm Beach, Queensland, Australia. Coastal Engineering Proceedings, No 34, sediment.23. http://dx.doi.org/10.9753/icce.v34.sediment.23

KRISTENSEN S., DEIGAARD R., TAANING M., FREDSØE J., DRØNEN N., JENSEN J.H. (2010). Long term morphological modelling, Coastal Engineering Proceedings. No 32, sediment.64 http://dx.doi.org/10.9753/icce.v32.sediment.64

DRØNEN N., KRISTENSEN S., TAANING M., ELFRINK B., DEIGAARD R. (2011). Long term modeling of shoreline response to coastal structures, in The Proceedings of Coastal Sediments, World Scientific, Miami, Florida. 